\title{
Nová dimenze kontroly krevního tlaku a kardiovaskulární prevence - symposium firmy Servier na XVII. výročním sjezdu ČKS
}

\author{
V průběhu sjezdu České kardiologické společnosti proběhlo v pondělí (11. 5. 2009) odpoledne \\ v sále Rotunda slavnostní symposium společnosti Servier na téma Nová dimenze kontroly \\ krevního tlaku a kardiovaskulární prevence. Na sympoziu zazněla tři sdělení:
}

\section{J. Špinar J: Význam správně zvolené kombinační léčby hypertenze. The state of art lecture R. Ferrari: Combination treatment based on ACE inhibitor perindopril. The importance of cardioprotection}

\section{A. Linhart: Synergický účinek kombinace perindopril/amlodipin}

Symposium uvedl prof. Špinar přivítáním významného hosta kongresu a zároveň přednášejícího na symposiu prof. Ferrariho. Ve své úvodní přednášce hovořil prof. Špinar o významu správně zvolené strategie léčby hypertenze. Hypertenze je stále závažný problém kardiologie, jak vyplývá z projektu Czech Post-MONICA, navzdory znalostem o účinku léčby a aktuálním doporučením dosahuje $\mathrm{v}$ průměrné české populaci kontrola krevního tlaku (TK) jen necelých $20 \%$ pacientů. Přitom evropská i národní doporučení jasně říkají, že cílem léčby je snížit kardiovaskulární riziko, čehož dosahujeme tím, že snížíme systolický krevní tlak na $<140 \mathrm{~mm} \mathrm{Hg} \mathrm{a}<130 \mathrm{~mm} \mathrm{Hg} \mathrm{u} \mathrm{diabe-}$ tiků a nemocných $\mathrm{s}$ onemocněním ledvin. Jednou $\mathrm{z}$ příčin nedostatečné léčby hypertenze je, že se vhodně neužívá kombinační léčba, kterou vyžaduje až 80 \% hypertenzních pacientů. Přitom v již zmíněném projektu Czech Post-MONICA mělo v roce 2000/2001 kombinaci dvou a více antihypertenziv pouze 53,3 \% léčených hypertoniků (v roce 1998 48,8 \%) (viz obrázek 1). Na nutnost kombinační léčby poukazují i současná doporučení České společnosti pro hypertenzi, která mimo jiné umožňují zahájit léčbu kombinací dvou antihypertenziv tehdy, je-li TK o 20/10 mm Hg nad normu, tj. > 160/100 mm Hg. Současné požadavky na kombinační léčbu: použití léků s rozdílným, pokud možno komplementárním mechanismem účinku, který tak zajistí vyšší účinnost s minimalizací nežádoucích účinků souvisejících s některou složkou přípravku. Moderní kombinační léčba by měla také svým pacientům poskytnout větší specifickou ochranu cílových orgánů a nižší riziko kardiovaskulárních př́hod. Použití fixních kombinací navíc zajistí lepší dodržování léčebného režimu (compliance), a tedy i vyšší antihypertenzní účinnost, jak doložili ve své metaanalýze Law a spol. Výhody a nevýhody fixních kombinací ukazuje tabulka 1.

$\mathrm{V}$ registru REACH byly nalezeny u $90 \%$ hypertenzních pacientů tři a více rizikové faktory. Odpovídá to i skutečné klinické praxi, kdy má naprostá většina hypertoniků některý z rizikových faktorů (nejčastěji kouření, dyslipidemii) či přidružené onemocnění (ischemickou chorobu srdeční - ICHS). Proto je nutné při volbě antihypertenzní léčby brát v úvahu také přítomnost přidružených onemocnění či rizikových faktorů. Kontrola hypertenze je velmi důležitá, ale existuje celá řada klinických situací, kde upřednostňujeme určitou třídu/třídy antihypertenziv před jinými, a to díky důkazům, které uvedl ve svém sdělení prof. Špinar. Poskytl zároveň řadu důkazů, např́íklad ze studie EUROPA, které ukázaly, že inhibitor ACE perindopril u nemocných $\mathrm{s}$ ICHS snižuje mortalitu/morbiditu i při TK < 140/90 mm Hg; ze studie ADVANCE, kde kombinace inhibitoru ACE perindoprilu s indapamidem snížila u nemocných s diabetes mellitus (bez ohledu na prítomnost hypertenze) celkovou a kardiovaskulární mortalitu a morbiditu, a v neposlední řadě z tlakové větve studie ASCOT. Ta ukázala, že stejný pokles krevního tlaku může být provázen rozdílným poklesem mortality a tedy, že na výběru antihypertenziva záleží (viz obrázky 2 a 3).

Význam kontroly TK v prevenci kardiovaskulárních (KV) př́hod je natolik důležitý, že je potřebné hledat další možnosti účinné antihypertenzní léčby v kontextu prokazatelně účinných antihypertenzních strategií. To si uvědomují rovněž současná česká, ale i evropská doporučení pro léčbu hypertenze. „Fixní kombinace jsou u nás v České republice a také jinde ve světě $\mathrm{k}$ dispozici, aby umožnily užívání dvou účinných látek $\mathrm{v}$ jediné tabletě, a tím zajistili optimální compliance s léčbou", uvedl na závěr svého sdělení prof. Špinar.

$\mathrm{Na}$ úvod své přednášky prof. Ferrari hovořil o úspěchu kardiologie. Za posledních 50 let se prodloužila očekávaná dálka života o deset let. Kardiologie se na tomto prodloužení podílí plnými sedmi lety! Na zlepšení prognózy nemocných s KV onemocněním se významnou měrou podílela také medikamentózní léčba. Klíčem tohoto úspěchu, jak uvedl prof. Ferrari, je relativně jednoduchý koncept: kontinuální progrese kardio- 


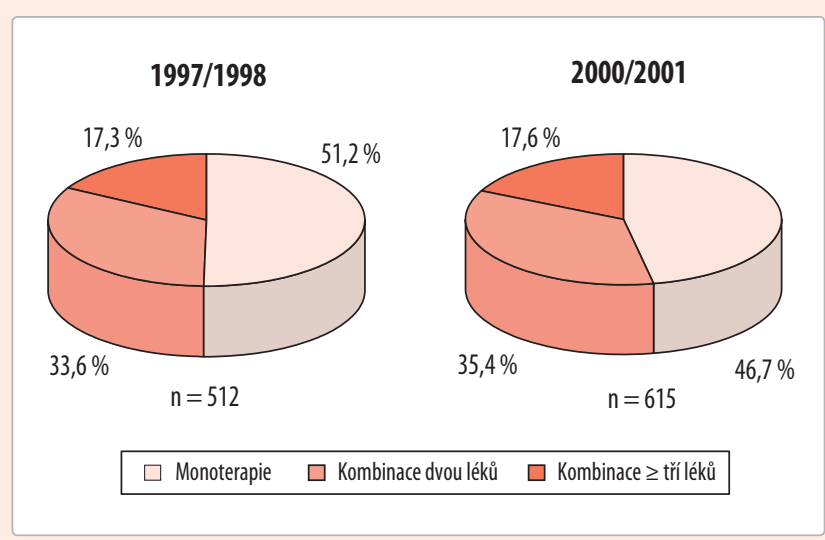

Obrázek 1 Antihypertenzní léčba v České republice

vaskulárního onemocnění, která vede k rozdílným, ale zároveň spolu souvisejícím klinickým př́hodám, k tzv. kardiovaskulárnímu kontinuu. Tento model progrese $\mathrm{KV}$ onemocnění začíná př́tomností rizikových faktorů, jako je hypertenze, dyslipidemie či diabetes mellitus, a vede přes ischemickou chorobu srdeční $\mathrm{k}$ infarktu myokardu, srdečnímu selhání až k úmrtí. Velmi důležitou roli $\mathrm{v}$ tomto kontinuu hraje progrese aterosklerózy a poškození endotelu.

Z klinických studií zaměřených na různé oblasti KV kontinua víme, že je možné přerušit tento řetězec př́hod. $\mathrm{V}$ tomto ohledu je zcela nezastupitelné postavení inhibitorů ACE, které se uplatňují v různých fázích KV kontinua, od nekomplikované hypertenze až po manifestní KV onemocnění. Prof. Ferrari uvedl, že v této oblasti je nejvíce údajů ze studií s perindoprilem, jehož příznivé účinky byly ve studiích ADVANCE, ASCOT, EUROPA, PROGRESS, PREAMI a PEP CHF dokumentovány u více než 50000 nemocných (obrázek 4). Prof. Ferrari následně položil otázku, jakými mechanismy uplatňuje perindopril své kardioprotektivní účinky?

Nepochybně se na příznivém účinku podílí jeho vliv na pokles TK. Studie EUROPA ale rovněž ukázala, že příznivý vliv perindoprilu byl přítomen bez ohledu na vstupní hodnoty TK; byl přítomen i u těch pacientů, u nichž nedošlo $\mathrm{k}$ poklesu TK během léčby a pokles ve výskytu KV příhod byl vyšší, než lze přisoudit samotnému poklesu TK. Druhým mechanismem vysvětlujícím příznivý vliv perindoprilu je protekce endotelu a následné zpomalení ći dokonce zastavení procesu aterosklerózy. Chronická nadměrná exprese tkáňového inhibitoru ACE u pacientů s manifestní ICHS poškozuje rovnováhu mezi angiotensinem II a bradykininem, s následnou dysfunkcí endotelu. Perindopril snižuje tvorbu angiotensinu II, tím brání vasokonstrikci, snižuje adhezi molekul a růstových faktorů, snižuje oxidační stres a brání nadměrné apoptóze buněk. Zároveň brání

\section{Tabulka 1 Výhody a nevýhody fixních kombinací}

\begin{tabular}{ll}
\hline Výhody & Nevýhody \\
\hline $\begin{array}{l}\text { Jednoduché dávkování } \\
\text { pro lékaře i pacienta }\end{array}$ & Někdy nevhodné dávky \\
\hline Zlepšená compliance & Obtí̌nější titrace \\
\hline Větší účinnost & $\begin{array}{l}\text { Obtižnější posouzení účinnosti } \\
\text { jednotlivých léků }\end{array}$ \\
\hline Lepší snášenlivost & $\begin{array}{l}\text { Obtižnější posouzení nežádoucích } \\
\text { účinků jednotlivých léků }\end{array}$ \\
\hline Většinou nižší cena & $\begin{array}{l}\text { Velký pokles krevního tlaku } \\
\text { při zahájení léčby }\end{array}$ \\
\hline
\end{tabular}

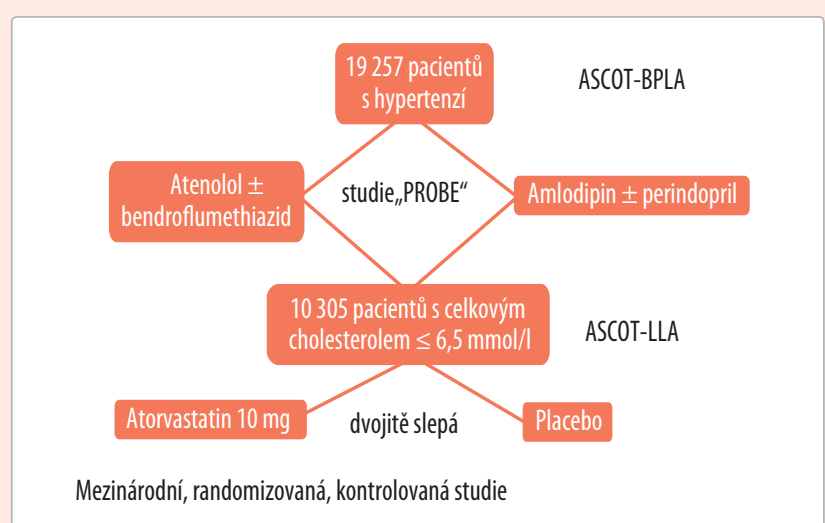

\section{Obrázek 2 Uspořádání studie ASCOT}

nežádoucí degradaci bradykininu. Umožňuje tak vasodilataci a brání apoptóze buněk. Pro tyto mechanismy dnes máme důkazy z klinické studie PERTINENT (podstudie EUROPA), která sledovala markery endoteliální funkce. Ukázala mimo jiné, že perindopril normalizoval u pacientů s ICHS rovnováhu mezi angiotensinem II a bradykininem, snížil ukazatele zánětu, bránil apoptóze buněk. Je pravděpodobné, že se v tomto případě nejedná o skupinový účinek; vysvětlením může být rozdílná afinita ke tkáňovému inhibitoru ACE, penetrace do aterosklerotického plátu.

Svou roli v patogenezi KV kontinua mají rovněž buňky hladké svaloviny cév, které jsou zodpovědné za udržení tonu cévního řečiště. Blokátory kalciových kanálů snižují př́sun iontů vápníku do buněk hladké svaloviny cév, a vedou tak $\mathrm{k}$ vasodilataci. Tento účinek blokátorů kalciových kanálů je ale odlišný od vasodilatačního účinku inhibitorů ACE. Inhibitory ACE způsobují vasodilataci zvýšením koncentrací bradykininu a také zvýšenou tvorbou NO v endotelu, přičemž oba tyto mechanismy způsobují vasodilataci. Tento synergický účinek inhibitorů ACE a blokátorů kalciových kanálů je jistě klinicky velmi zajímavý nejen pro možnost účinné kontroly TK, ale také pro další zpomalení remodelace na úrovni cév a vaskuloprotekci. Prof. Ferrari uzavřel své sdělení připomenutím významu inhibitorů ACE a blokátorů kalciových kanálů $\mathrm{v}$ doporučeních Evropské kardiologické společnosti a otázkou, zda bude možné použít kombinaci perindoprilu a blokátoru kalciových kanálů nejen samostatně, ale také jako fixní kombinaci.

Odpovědět na tuto otázku se pokusil ve své přednášce prof. Linhart, který se zaměřil na doklady o synergickém účinku kombinace perindoprilu a amlodipinu. V duchu kardiovaskulárního kontinua uvedl, že cílem léčby hypertenze dnes již

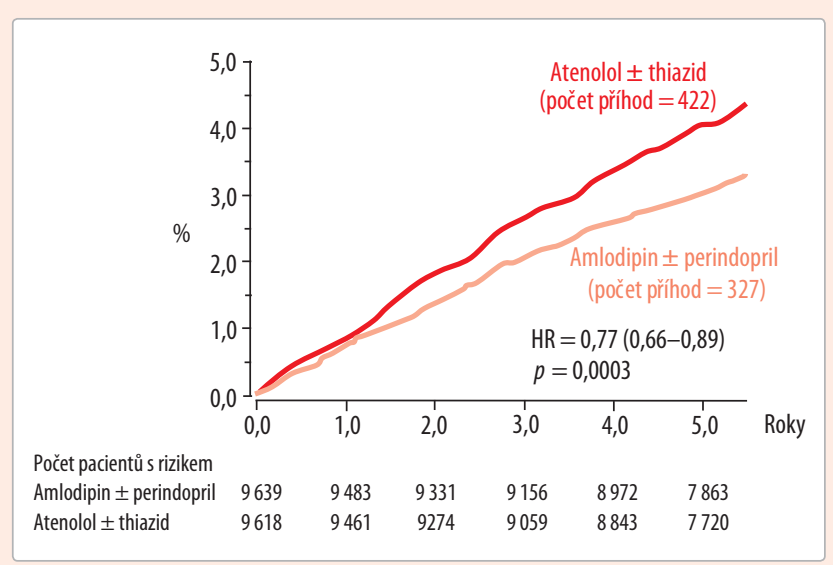

Obrázek 3 Fatální a nefatální cerebrovaskulární př́íhody ve studii ASCOT 


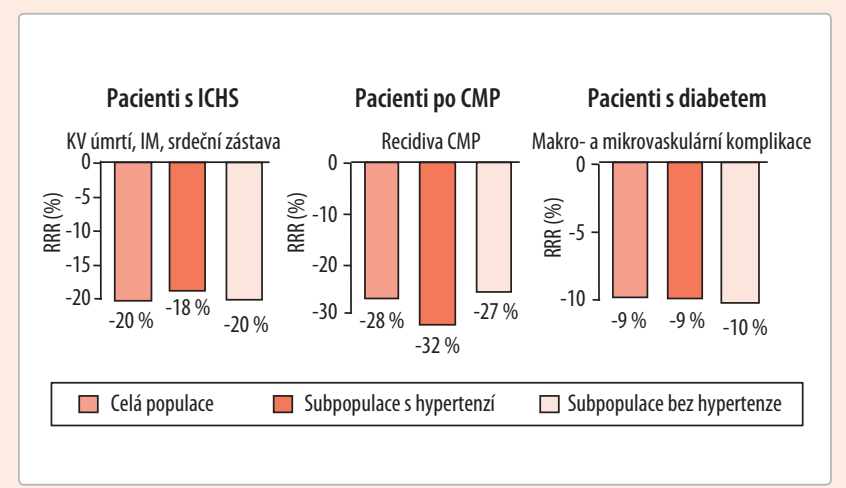

Obrázek 4 Účinek perindoprilu u pacientů s hypertenzí i bez hypertenze

ICHS - ischemická choroba srdeční, KV - kardiovaskulární, IM - infarkt myokardu, CMP - cévní mozková příhoda

není jen zpomalit progresi již manifestního KV onemocnění, ale vhodně zvolenou léčbou se zaměřit na klinické stavy, jež předcházely vzniku manifestního KV onemocnění. Dnešním terapeutickým cílem je tedy vaskulární či dokonce endoteliální dysfunkce; jejich ovlivnění léčbou by mohlo oddálit či dokonce zabránit progresi do manifestního onemocnění, a tak významně zlepšit prognózu nemocného. Z klinické praxe víme, že $s$ přibývajícím věkem ztrácí arteriální řečiště poddajnost. Důsledkem toho je nejen vzestup systolického TK s věkem, ale také zvýšený pulsní tlak. Ztráta poddajnosti také způsobuje zhoršenou myokardiální spotřebu a dodávku $\mathrm{O}_{2}$. V současnosti jsme schopni vyšetř̌it funkční stav cévního řečiště. Jednou z možností je neinvazivní záznam rychlosti šiření pulsní vlny, která má velmi dobrý korelát s prognózou nemocného. Anatomie arteriálního stromu umožňuje současné šíření dopředné a odražené pulsní vlny. Odražená vlna může při snížené poddajnosti arteriálního řečiště významně navýšit pulsní tlak. Míru, jakou se odražená pulsní vlna podílí na vzestupu pulsního tlaku, vyjadřuje augmentační index, jehož zvýšená hodnota vypovídá o zvýšeném riziku KV př́hody či úmrtí.

Dnes jsme schopni funkční stav cévního řečiště nejen vyšetřit, ale především léčebně ovlivnit. Víme také, že různé skupiny antihypertenziv různě ovlivňují centrální aortální a periferní TK. Studie Morgana a spol. ukázala, že pouze inhibitory ACE a blokátory kalciových kanálů snížily jak periferní brachiální, tak i centrální aortální TK. Studie s perindoprilem ukazují jeho

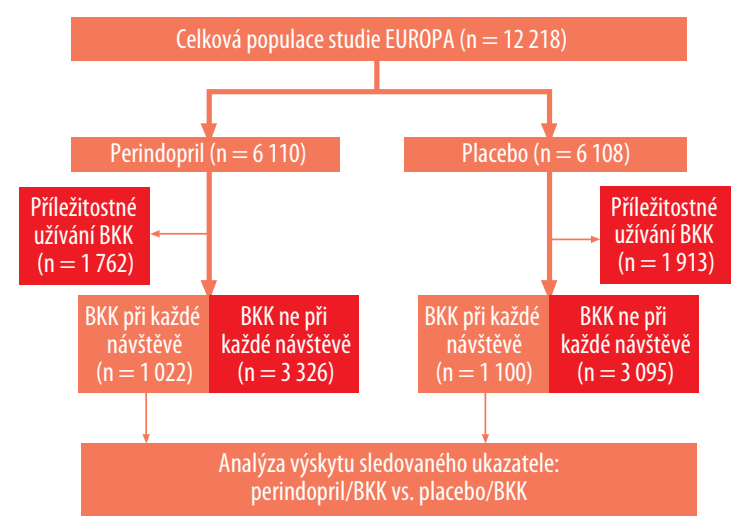

Obrázek 5 Synergický účinek perindoprilu a blokátorů kalciových kanálů: analýza studie EUROPA post hoc

BKK - blokátory kaciových kanálů

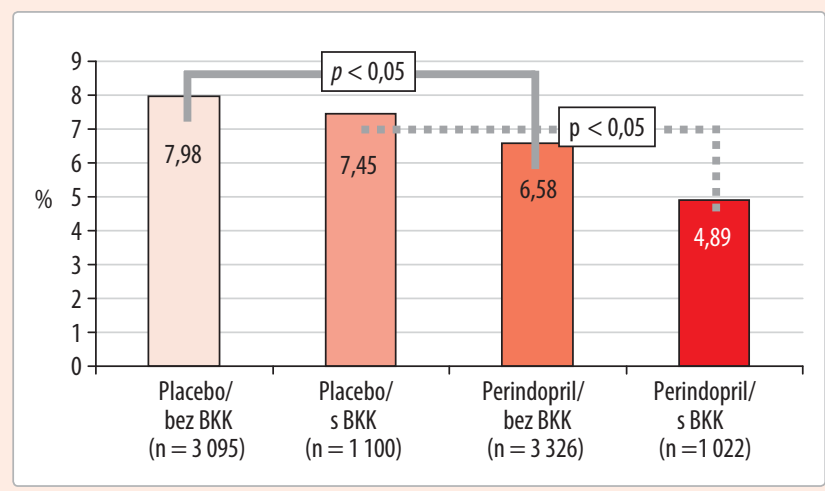

Obrázek 6 Primární ukazatel (kardiovaskulární úmrtí, infarkt myokardu, zresuscitovaná srdeční zástava): analýza studie EUROPA post hoc

BKK - blokátory kalciových kanálů

schopnost příznivě ovlivnit strukturu a funkci arteriálního řečiště. Léčba perindoprilem je schopna zpomalit rychlost šíření pulsní vlny; ve studii REASON snížila augmentační index, ve studii DAPHNET zvýšila poddajnost karotických tepen a vedla $\mathrm{k}$ regresi remodelace na úrovni malých rezistenčních arteriol. Obdobně amlodipin ve studii PREVENT snížil intimo-mediální tlouštku karotid, ve studii NORMALIZE vedl k regresi aterosklerotických plátů. Z metaanalýzy Verdecchiiho a spol. navíc vyplývá, že příznivý vliv inhibitorů ACE a blokátorů kalciových kanálů se uplatňuje rozdílnými mechanismy. Inhibitory ACE jsou účinnější na snížení rizika KV př́hod, a blokátory kalciových kanálů naopak na pokles cévních mozkových př́íhod (CMP).

Výše zmíněnému příznivému ovlivnění hemodynamiky velkých tepen odpovídá zlepšená prognóza hypertenzních pacientů. Ve studii CAFE (podstudie ASCOT) byl měřen nejen periferní brachiální TK, ale byla také měřena pulsní vlna radiální arterie neinvazivně aplanačním tonometrem. Oba léčebné režimy amlodipin \pm perindopril a atenolol \pm thiazid srovnatelně ovlivnily periferní brachiální TK, centrální hemodynamiku však ovlivnily rozdílně, amlodipin \pm perindopril snížil centrální systolický TK oproti srovnávané léčbě významně více (rozdíl $-4,3 \mathrm{~mm} \mathrm{Hg}, p<0,0001)$. To je nepochybně jedním $\mathrm{z}$ vysvětlení př́znivého účinku amlodipinu \pm perindoprilu na pokles $\mathrm{KV}$ mortality a dalších sledovaných parametrů studie ASCOT. Dalším vysvětlením by mohla být metabolická výhodnost kombinace amlodipinu \pm perindoprilu ve srovnání $s$ atenololem \pm thiazidem, uvedl prof. Linhart. To opět dokládá studie ASCOT. Zkřížením lipidové a tlakové větve studie ASCOT se navíc ukázalo, že protektivní účinek statinu se uplatnil v kombinaci $s$ amlodipinem \pm perindoprilem, nikoli však v kombinaci s atenololem \pm thiazidem. Tyto výsledky jsou v souladu nejen $s$ již zmíněnou studií ACCOMPLISH, ale také s nedávno prezentovanou analýzou ze studie EUROPA. Ukázala, že z př́znivého účinku perindoprilu měli největši prospěch ti nemocní, kteří při vstupu do studie užívali blokátor kalciového kanálu (obrázky 5 a 6).

Kombinace inhibitoru ACE a blokátoru kalciového kanálu účinně ovlivňuje hemodynamiku velkých tepen, působí metabolicky šetrně a je účinnější v ovlivnění KV morbidity a mortality než srovnávané kombinace, uzavřel své sdělení a celé symposium prof. Linhart.

Prof. MUDr. Jindřich Špinar, CSc., Interní kardiologická klinika, FN Brno a LF MU, Brno, e-mail: jspinar@med.muni.cz 